\title{
Translocation of residual tricyclazole from soil to Korean cabbage
}

\author{
Eun-Jung Hwang ${ }^{1} \cdot$ Kyu-won Hwang ${ }^{1}$ Min-Gi Kim ${ }^{1}$ Chae-Ho Jeon ${ }^{1}$. \\ Joon-Kwan Moon $^{1}$
}

\section{엇갈이 배추 재배토양 중 살균제 Tricyclazole의 작물 전이량}

황은정 ${ }^{1} \cdot$ 황규원 $^{1} \cdot$ 김민기 $^{1} \cdot$ 전채호 $^{1} \cdot$ 문준관 $^{1}$

Received: 18 July 2017 / Accepted: 8 September 2017 / Published Online: 31 December 2017

(C) The Korean Society for Applied Biological Chemistry 2017

\begin{abstract}
This study was carried out to investigate the residual level of 5-methyl-1,2,4-triazolo[3,4-b][1.3] benzothiazole (tricyclazole) and the amount of transfer to Korean cabbage grown in treated soil with tricyclazole. The field trial on Korean cabbage was done at two different green houses located in Gwangju (Field 1) and Yongin (Field 2). Soil and cabbage samples were collected at different days after soil treatment of tricyclazole with two different concentration levels, respectively. Average recoveries of tricyclazole ranged from 83.5 to $92.1 \%$ in soil and cabbage and the variation coefficient was $1.3-6.8 \%$. The initial concentrations of tricyclazole in field 1 soil were 4.25 and $8.97 \mathrm{mg} / \mathrm{kg}$ and decreased to 2.48 and $4.26 \mathrm{mg} / \mathrm{kg}$ at 43 DAT (day after treatment) and 0.88 and $2.02 \mathrm{mg} /$ $\mathrm{kg}$ and decreased to 0.43 and $0.98 \mathrm{mg} / \mathrm{kg}$ at 36 DAT in field 2, respectively. The half-life of tricyclazole was about 39.6 and 28.1 days for the low and high concentration of tricyclazole treated soils in field 1 and 27.9 and 17.2 days for the low and high concentration of tricyclazole treated soils in field 2, respectively. Residual levels of tricyclazole in Korean cabbage were ranged from 4.03 to 18.26 and from 8.26 to $35.08 \%$ of initial concentration in filed 1 and field 2 soils, respectively.
\end{abstract}

Joon-Kwan Moon $(\bowtie)$

E-mail: jkmoon@hknu.ac.kr

${ }^{1}$ Department of Plant Life and Environmental Sciences, Hankyong National University, 327 Jungang-ro, Ansung 17579, Republic of Korea

This is an Open Access article distributed under the terms of the Creative Commons Attribution Non-Commercial License (http://creativecommons. org/licenses/by-nc/3.0/) which permits unrestricted non-commercial use, distribution, and reproduction in any medium, provided the original work is properly cited.
Keywords Fungicide $\cdot$ Korean cabbage $\cdot 5$-methyl-1,2,4triazolo[3,4-b][1.3] benzothiazole $\cdot$ Soil residue $\cdot$ Translocation

\section{서 론}

5-methyl-1,2,4-triazolo[3,4-b][1.3] benzothiazole (Tricyclazole) 은 triazole계 침투성 살균제로서(Table 1), 뿌리에 의해서 흡수 가 되고 식물체내 물관부와 아포플라스트로 전이되는 것으로 알 려져 있다(Tomlin 2015).

국내에서는 벼의 도열, 무늬병, 세균성 벼알마름병 방제용으 로 등록되어 사용되고 있지만(KCPA 2016), 배추에 대한 잔류 허용기준은 설정되어 있지 않다.(Ministry of Food and Drug Safety 2017). 국립 농산물 품질관리원 2016년 농산물 안전성조 사결과에 따르면 tricyclazole은 사용등록 되어있지 않은 부추에 서 부적합 농약 성분으로 검출된 이력이 있다(National Agricultural Quality Service 2017). 등록되어 있지 않은 작물에 영향을 주는 요인은 부적절한 농약 사용 및 토양 중 잔류농약의 흡수이행 현상일 수 있는데, 살포된 농약은 직접 살포, 낙하, 강수 등에 의해 토양으로 이동하여 잔류하게 되고, 토양 중 잔류 농약은 미생물 분해, 유출, 광분해, 식물체로의 흡수 등으로 분해 감소 하게 된다(Park et al. 2013). 우리나라에서 사용되고 있는 농약 의 토양 반감기는 대부분 30 일 이내이고, 반감기가 180 일을 넘 기거나 그 이하일지라도 후작물에 흡수될 우려가 있다(Kim 등, 2017). Tricyclazole은 담수조건에서 2-3주까지는 빠르게 분해되 다가 140-180일 에서는 안정적으로 분해가 되고(Hwang 등, 1985), 토양 반감기는 표층토의 경우 305일(Phong 등, 2009)등 으로 알려져 있다. 따라서 반감기가 긴 tricyclazole은 토양에 잔 류하여 후작물에 영향을 줄 가능성이 높아 토양 중 잔류량 관 리가 필요하다. 
Table 1 Physico-chemical properties of tricyclazole (Tomlin, 2015)

\begin{tabular}{ll}
\hline Common name: & tricyclazole \\
IUPAC name: & 5-methyl-1,2,4-triazolo[3,4-b] [1,3] \\
Molecular weight: & benzothiazole \\
Molecular formular: & 189.2 \\
Vapor pressure $(\mathrm{mPa}):$ & $\mathrm{C}_{9} \mathrm{H}_{7} \mathrm{~N}_{3} \mathrm{~S}$ \\
Melting point: & $5.86 \times 10^{-4}\left(20^{\circ} \mathrm{C}\right)$ \\
$\mathrm{K}_{\text {ow }}$ logP: & $184.6-187.2^{\circ} \mathrm{C}$ \\
Solubility: & 1.42 \\
& $0.596\left(\right.$ water, g/L, 20 $\left.{ }^{\circ} \mathrm{C}\right)$ \\
& acetone 13.8, methanol 26.5, xylene 4.9 \\
& $\left(\right.$ all, g/L, 20 $\left.0^{\circ} \mathrm{C}\right)$ \\
\hline
\end{tabular}

토양 중 잔류하는 농약은 작물의 뿌리를 통해 흡수되어 줄기, 잎 및 과실 등으로 이행될 수 있고, 흡수되는 정도는 작물, 농 약의 이화학적 특성과 침투성에 따라 달라질 수 있으며 엇갈이 배추와 같은 엽채류의 경우 뿌리로 농약이 흡수되어 바로 가식 부에 이동하기 때문에 토양에 잔류하는 농약에 대해 작물이 영 향을 받을 수 있다(Jeon 등, 2014). 따라서 농산물 안정성을 확 보하기 위해 작물 및 농약의 이화학적 특성에 따른 토양잔류농 약의 작물흡수이행과 잔류전이량 연구는 매우 중요하다. 엽채류 중 하나인 엇갈이 배추는 작물과 작물 사이에 경작지가 가용한 짧은 기간을 이용하여 사이짓기로 재배되기 때문에 재배특성 상 처음 재배할 때 살포된 농약이 토양 중에 잔류한 뒤 후재배작 물에 영향을 미칠 가능성이 높다(Jeon 등, 2014).

본 연구에서는 엽채류인 엇갈이 배추중 살균제 tricyclazole의 작물전이량을 구명하기 위해 tricyclazole이 살포된 토양에서 재 배 후, 수확시 작물중 잔류량을 분석하고, 농산물의 안정성을 확보할 수 있는 토양관리농도 제안의 기초자료로 활용하고자 하 였다.

\section{재료 및 방법}

\section{시약, 재료 및 기구}

Tricyclazole 표준품(순도 99.7\%)은 Sigma Aldrich (St. Louis, $\mathrm{MO}$, USA)에서 구입하였고, acetone, acetonitrile, dichloromethane, hexane은 HPLC급을 (J.T. Baker, Phillipsburg, NJ, USA)에서 구입하였다. Sodium chloride, 무수 sodium sulfate는 GR급을 Samchun Chemical, 평택, 대한민국)에서 구입하여 사용하였다. 추출 후 정제는 SPE cartridge (Amine, $1 \mathrm{~g}$, Phenomenex, Torrance, CA, USA)를 이용하여 실시하였다.

채취한 배추 시료는 Mixer (NFM-8860, NYC, 서울, 대한민 국)를 이용하여 마쇄하였고, 진탕기(SK-600 Shaker, JEIO Tech, 대전, 대한민국)는 시료 추출시 사용하였고, 감압농축기(EYELA, Tokyo, Japan)와 질소증발기(Hurricane-Lite, Cheongmin Tech, 서 울, 대한민국)는 시료 추출액 농축시 사용하였다. 살포용 농약 Tricyclazole $75 \%$ 수화제(가야빔, (주)경농, 서울, 대한민국, $75 \%$ $\mathrm{WP})$ 는 시중 농약상에서 구입하였다.
Table 2 HPLC operation condition for the analysis of tricyclazole in soil and cabbage

\begin{tabular}{ll}
\hline \hline Instrument & Agilent 1100 series \\
Detector & Variable Wavelength Detector (VWD) \\
Column & Kinetex C18 $(4.6 \times 250 \mathrm{~mm}, 5 \mu \mathrm{m}$ particle size) \\
Mobile Phase & A (water), B (acetonitrile) $=\mathrm{A} / \mathrm{B}=80 / 20$ \\
Flow rate & $1.1 \mathrm{~mL} / \mathrm{min}$ \\
Wavelength & $224 \mathrm{~nm}$ \\
Injection volume & $5 \mu \mathrm{L}$ \\
Retention time & $14.5 \mathrm{~min}$ \\
\hline
\end{tabular}

\section{공시 작물 및 농약 처리}

공시 농작물인 엇갈이 배추는 ‘참멋진 엇갈이'(동오시드, (주)경 농, 서울, 대한민국) 품종으로, 시험 포장 1 은 경기도 광주시와, 시험 포장 2은 용인시에 위치한 농장에서 시설재배 하였고, 파 종 전 로타리 작업을 실시하여 토양을 균질화 하고 tricyclazole $75 \%$ 수화제(가야빔)를 시험포장 1 (광주, soil 1)의 경우, $4.8 \mathrm{~g}$ (Treatment 1), $9.6 \mathrm{~g}$ (Treatment 2)을 취하고 물 $5 \mathrm{~L}$ 로 희석하 여 $2.5 \mathrm{~m} \times 4 \mathrm{~m}$ 의 토양 표면에 고르게 살포하였고, 시험포장 2 (용 인, soil 2)의 경우 각각 $0.8 \mathrm{~g}$ (Treatment 1 ), $1.6 \mathrm{~g}$ (Treatment 2)을 취하고 $2 \mathrm{~L}$ 물로 희석하여 $2.2 \mathrm{~m} \times 2.4 \mathrm{~m}$ 의 토양 표면에 고 르게 처리하였다. 약제 처리 후 배추를 재식간격 $20 \mathrm{~cm} \times 20 \mathrm{~cm}$ 로 파종하였다. 시험포장 1 의 토양은 사양토로 $\mathrm{pH}$ 는 $5.1, \mathrm{EC}$ 는 $6.8 \mathrm{dS} / \mathrm{m}$, 유기물 함량은 $13 \mathrm{~g} / \mathrm{kg}$ 이었고, 포장 2 토양은 양토로 서 $\mathrm{pH}$ 는 $5.8, \mathrm{EC}$ 는 $10.39 \mathrm{dS} / \mathrm{m}$, 유기물 함량은 $19 \mathrm{~g} / \mathrm{kg}$ 이었다.

\section{시료 채취}

토양시료는 농약살포 3 시간 후 0 일로 하여 포장 1 의 경우 0,7 , $14,35,39,43$ 일차에 채취하였고, 포장 2 의 경우 $0,7,14,22$, 28 일차에 채취하였다. 채취한 토양은 즉시 음건하여 $2 \mathrm{~mm}$ 체로 거른 후 분석에 사용하였다. 배추 시료는 포장 1 의 경우 파종 후 $35,37,39,41,43$ 일차에 채취하였고, 포장 2 의 경우 22,25 , $28,32,36$ 일차에 채취하였다. 엇갈이 배추 시료는 채취 후 흐르 는 물로 외부에 부착된 농약을 세척하고 뿌리 및 물기를 제거한 지상부 무게를 측정한 후 드라이아이스를 첨가하여 믹서기로 균 질하게 분쇄 한 후 분석 직전까지 $-20^{\circ} \mathrm{C}$ 냉동고에 보관하였다.

\section{기기 분석 조건}

토양과 엇갈이배추 시료 중 tricyclaozle의 분석은 Variable Wavelength Detector (VWD)가 장착된 Agilent 1100 series HPLC (Agilent, Santa Clara, CA, USA)를 사용하였고 기기조 건은 Table 2과 같다.

\section{표준검량직선 작성}

Tricyclazole standard (99.7\%) $100.30 \mathrm{mg}$ 을 acetonitrile $100 \mathrm{~mL}$ 에 용해하여 $1,000 \mathrm{mg} / \mathrm{L}$ 의 표준용액을 제조하였다. 이 표준용액 을 acetonitrile로 단계적으로 희석하여 $0.1,0.5,1.0,5.0$, $10.0 \mathrm{mg} / \mathrm{L}$ 의 분석 표준용액을 제조한 후 HPLC-VWD에 각각 $5 \mu \mathrm{L}$ 를 주입하여 나타난 크로마토그램상의 피크면적을 기준으 로 표준검량직선을 작성하였다. 


\section{토양 중 Tricyclazole의 분석}

토양 $20 \mathrm{~g}$ 을 취하여 증류수 $30 \mathrm{~mL}$ 를 가하고 1 시간 정치한 후 $100 \mathrm{~mL}$ acetone을 가하여 진탕기로 30 분간 $200 \mathrm{rpm}$ 으로 추출 하였다. 추출액을 Büchner funnel로 흡인여과하고 $30 \mathrm{~mL}$ acetone으로 잔사 및 용기를 씻어 앞의 여액과 합하였다. 여액 을 $500 \mathrm{~mL}$ 분액여두에 옮기고 $20 \mathrm{~mL}$ 포화식염수와 $80 \mathrm{~mL}$ 증 류수를 차례로 가한 후 dichloromethane $70 \mathrm{~mL}$ 로 2회 분배 추 출하였다. Dichloromethane 추출액을 $20 \mathrm{~g}$ 의 anhydrous sodium sulfate에 통과하여 탈수하고 $40{ }^{\circ} \mathrm{C}$ 수욕상에서 감압농축 한 후 dichloromethane $2 \mathrm{~mL}$ 에 재용해하여 정제과정에 사용하였다. dichloromethane $5 \mathrm{~mL}$ 로 활성화 시킨 $\mathrm{SPE}-\mathrm{NH}_{2}(1 \mathrm{~g})$ catridge 에 재용해된 분석시료를 가하고, $8 \mathrm{~mL}$ methanol/dichloromethane $(5 / 95, v / v)$ 으로 용출시켜 그 용출액을 질소건고 하였다. 건고 후 acetonitrile $4 \mathrm{~mL}$ 로 재용해하여 각각 $5 \mu \mathrm{L}$ 씩 $\mathrm{HPLC}-\mathrm{VWD}$ 에 주 입하여 나타난 chromatogram상의 peak area를 표준검량직선과 비교하여 잔류량을 계산하였다.

\section{엇갈이 배추 중 Tricyclazole의 분석}

마쇄된 엇갈이 배추시료 $10 \mathrm{~g}$ 취하여 증류수 $30 \mathrm{~mL}$ 를 가하고 1 시간 정치한 후 $100 \mathrm{~mL}$ acetone을 가하여 진탕기로 30 분간 $200 \mathrm{rpm}$ 으로 추출하였다. 추출액을 Büchner funnel로 흡인여과 하고 $30 \mathrm{~mL}$ acetone으로 잔사 및 용기를 씻어 앞의 여액과 합 하였다. 여액을 $500 \mathrm{~mL}$ 분액여두에 옮기고 $20 \mathrm{~mL}$ 포화식염수 와 $80 \mathrm{~mL}$ 증류수를 차례로 가한 후 dichloromethane $70 \mathrm{~mL}$ 로 2회 분배 추출하였다. Dichloromethane 추출액을 $20 \mathrm{~g}$ 의 anhydrous sodium sulfate에 통과하여 탈수하고 $40{ }^{\circ} \mathrm{C}$ 수욕상에 서 감압농축 한 후 dichloromethane $2 \mathrm{~mL}$ 에 재용해하여 정제과 정에 사용하였다. dichloromethane $5 \mathrm{~mL}$ 로 활성화 시킨 $\mathrm{SPE}$ $\mathrm{NH}_{2}(1 \mathrm{~g})$ catridge에 재용해된 분석시료를 가하고, $8 \mathrm{~mL}$ methanol/dichloromethane $(5 / 95, \mathrm{v} / \mathrm{v})$ 으로 용출시켜 그 용출액을 질소건고 하였다. 건고 후 acetonitrile $2 \mathrm{~mL}$ 로 재용해하여 각각 $5 \mu \mathrm{L}$ 씩 HPLC-VWD에 주입하여 나타난 chromatogram상의 peak area를 표준검량직선과 비교하여 잔류량을 계산하였다.

\section{토양 및 엇갈이 배추 중 Tricyclazole의 회수율 확인}

Tricyclazole 표준용액 $10.0 \mathrm{mg} / \mathrm{L}$ 을 무처리 토양시료 $20 \mathrm{~g}$ 에 각 각 0.4 및 $2.0 \mathrm{~mL}$, 무처리 배추 $10 \mathrm{~g}$ 에 각각 $0.2,1.0 \mathrm{~mL}$ 첨가 하여 각각의 잔류량이 0.2 및 $1.0 \mathrm{mg} / \mathrm{kg}$ 이 되도록 처리한 후 위 의 잔류분석 방법으로 추출, 정제한 후 HPLC-VWD로 분석하 여 회수율을 계산하였다.

\section{반감기}

경과일별 토양 중 tricyclazole 잔류 감소는 Sigma Plot 프로그램 (Simasoft, 서울, 대한민국)을 이용하여 아래의 식에 적용하였다.

$$
\begin{aligned}
\mathrm{C}_{\mathrm{t}} & =\mathrm{C}_{0} \cdot \mathrm{e}^{-\kappa \mathrm{t}} \\
\ln \mathrm{C}_{\mathrm{t}} & =\ln \mathrm{C}_{0}-\kappa \mathrm{t}
\end{aligned}
$$

$\left(\mathrm{C}_{\mathrm{t}}\right.$ : 잔류량, $\mathrm{C}_{0}$ : 초기잔류량, $\mathrm{\kappa}$ : 감소상수, $\mathrm{t}$ : 시간 $)$

반감기는 $\ln 2 / \mathrm{k}$ 의 값으로 표현되며 $0.693 / \mathrm{k}$ 와 같다.

\section{결과 및 고찰}

\section{재배시설내 온도, 습도 및 엇갈이 배추의 중량변화}

엇갈이 배추 재배 기간 동안 포장 1 시설내의 일평균기온은 11.627 .7 었고, 일평균습도는 $46.085 .4 \%$, 포장 2 시설내의 일 평균기온은 15.927 .6 었고, 일평균습도는 $55.584 .2 \%$ 범위였다. 시료 채취시 엇갈이 배추의 평균 무게는 포장 1 저농도 처 리구에서는 35 일차 $142.4 \mathrm{~g}$ 에서 43 일차 $337.3 \mathrm{~g}$ 으로 증가하였 고, 고농도 처리구에서는 $84.1 \mathrm{~g}$ 에서 $167.0 \mathrm{~g}$ 으로 증가하였다. 포장 2 저농도 처리구에서는 22 일차 $9.3 \mathrm{~g}$ 에서 36 일차에 156.4 $\mathrm{g}$ 으로 증가하였고, 고농도 처리구에서는 $7.4 \mathrm{~g}$ 에서 $115.9 \mathrm{~g}$ 으로 증가하였다(Table 3 ).

\section{Tricyclazole 잔류 분석법 확립}

Tricyclazole의 표준검량선은 $1.0 \mathrm{ng}$ 에서 $100 \mathrm{ng}$ 까지 상관계수가 0.9998 로 직선성을 보였다.

최소 검출량(Limit of Detection, LOD)은 분석 크로마토그램 상에서 신호대 잡음비의 3배 이상을 나타내는 농약의 양을 말 하며 baseline으로부터 피크를 인정할 수 있는 최소의 양이다. 검출한계(Limit of Quantitation (LOQ))는 최소 검출량 또는 최 소검출농도, 시료량 및 분석조작 중의 희석배율 등을 감안하여 식 (1)과 (2)에 의해 산출된 수치로서 본 연구에 사용한 분석방 법으로 정량할 수 있는 한계를 의미하며 $0.05 \mathrm{mg} \mathrm{kg}^{-1}$ 이하를 추천하고 있다. 본 연구에 사용한 분석법의 검출한계는 $0.02 \mathrm{mg}$ $\mathrm{kg}^{-1}$ 으로서 잔류분석법 기준에 적합하였고 (KFDA 2015), 잔류 허용기준 (MRL) 이하까지 검출 가능하였다.

LOQ $(\mathrm{ppm})$, 토양=[최소검출량 $(0.5 \mathrm{ng}) \times \mathrm{HPLC}$ 주입전 시료용액 량 $(4 \mathrm{~mL}) \times$ 희석배수 $(1)] /[\mathrm{HPLC}$ 주입량 $(5 \mu \mathrm{L})$ 시료량 $(20 \mathrm{~g})]$ (1)

LOQ $(\mathrm{ppm})$, 배추=[최소검출량 $(0.5 \mathrm{ng}) \times \mathrm{HPLC}$ 주입전 시료용액 량 $(2 \mathrm{~mL}) \times$ 희석배수 $(1)] /[\mathrm{HPLC}$ 주입량 $(5 \mu \mathrm{L})$ 시료량 $(10 \mathrm{~g})]$ (2)

시료 용액의 분석 크로마토그램에서 tricyclazole의 머무름 시간 은 14.5 분 이었고, 중첩되는 방해물질은 없었다(Fig. 1). 회수율 시험결과 0.2 및 $1.0 \mathrm{mg} \mathrm{kg}^{-1}$ 수준 각각 토양 1 에서는 $86.5 \pm$ $3.0,90.0 \pm 2.8 \%$, 토양 2 에서는 $86.6 \pm 6.8,89.8 \pm 3.8 \%$, 엇갈이 배

\begin{tabular}{|c|c|c|c|c|c|}
\hline Field 1 & 35 DAT & 37 DAT & 39 DAT & $41 \mathrm{DAT}$ & 43 DAT \\
\hline Treatment 1 & $142.4 \pm 4.7$ & $182.2 \pm 7.3$ & $210.0 \pm 6.8$ & $198.8 \pm 2.1$ & $337.3 \pm 6.3$ \\
\hline Treatment 2 & $84.1 \pm 4.7$ & $105.2 \pm 6.1$ & $172.2 \pm 9.0$ & $167.4 \pm 2.8$ & $167.0 \pm 2.2$ \\
\hline Field 2 & $22 \mathrm{DAT}$ & $25 \mathrm{DAT}$ & $28 \mathrm{DAT}$ & $32 \mathrm{DAT}$ & $36 \mathrm{DAT}$ \\
\hline Treatment 1 & $9.3 \pm 1.8$ & $16.6 \pm 2.1$ & $43.0 \pm 6.7$ & $112.9 \pm 4.1$ & $156.4 \pm 4.3$ \\
\hline Treatment 2 & $7.4 \pm 2.6$ & $15.0 \pm 3.9$ & $42.4 \pm 2.9$ & $63.2 \pm 3.4$ & $115.9 \pm 3.7$ \\
\hline
\end{tabular}

Table 3 Weight changes of cabbage during cultivation (g) 

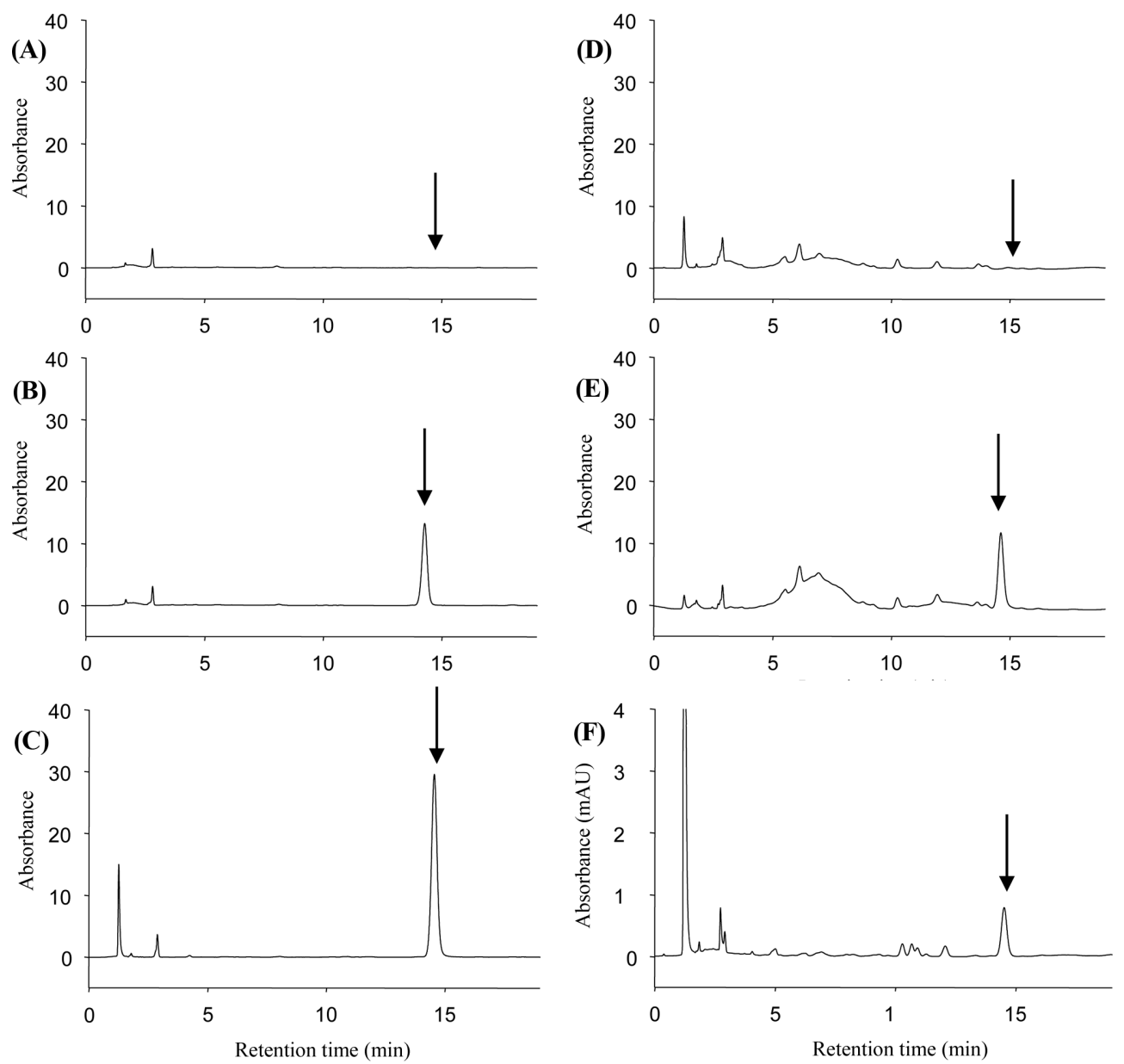

Fig. 1 HPLC chromatogram of soil 1 and cabbage sample. (A; soil control, B; fortified soil at $1.0 \mathrm{mg} \mathrm{kg}^{-1}$, C; soil sample of 43 day after application, $\mathrm{D}$; cabbage control, E; fortified cabbage at $1.0 \mathrm{mg} \mathrm{kg}^{-1}, \mathrm{~F}$; cabbage sample of 37 day after application)

추에서는 $92.1 \pm 2.0,83.5 \pm 1.3 \%$ 이었다(Table 4$)$, 이 결과 농약의 등록시험 기준과 방법에서 권고하는 $70-120 \%$, 변이계수 $20 \%$ 이내의 수준을 만족하였다(KFDA 2015).

\section{토양 중 잔류량 변화}

재배 토양 중 tricyclazole은 포장 1 저농도 처리구 초기 잔류농 도는 $4.25 \mathrm{mg} \mathrm{kg}^{-1}$ 에서 43 일 후 $2.48 \mathrm{mg} \mathrm{kg}^{-1}$ 로 감소되었고, 고 농도 처리구 잔류량은 초기에 $8.97 \mathrm{mg} \mathrm{kg}^{-1}$ 이었으며 43일 후에
는 $4.26 \mathrm{mg} \mathrm{kg}^{-1}$ 로 감소하였다. 재배 기간 중 tricyclazole은 1차 지수 함수적으로 잔류량이 감소하였다(Fig. 2).

잔류 감소 회귀식은 저농도 처리구는 $\mathrm{C}_{\mathrm{t}}=3.2366 \mathrm{e}^{-0.0175 \mathrm{t}}\left(\mathrm{R}^{2}\right.$ $=0.3855)$, 고농도 처리구는 $\mathrm{C}_{\mathrm{t}}=8.7210 \mathrm{e}^{-0.0247 \mathrm{t}}\left(\mathrm{R}^{2}=0.9206\right)$ 이었 고, 이 식에 따라서 산출된 포장 1 재배 토양 중 반감기는 각 각 $39.6,28.1$ 일 이었다.

포장 2 저농도 처리구 초기 잔류농도는 $0.88 \mathrm{mg} \mathrm{kg}^{-1}$ 이었으며 36 일 후에는 $0.43 \mathrm{mg} \mathrm{kg}^{-1}$ 로 감소 되었다. 고농도 처리구 초기

Table 4 Recoveries and limits of quantitation of tricyclazole

\begin{tabular}{|c|c|c|c|c|c|c|}
\hline \multirow{2}{*}{ Sample } & \multirow{2}{*}{$\begin{array}{l}\text { Fortification level } \\
\qquad\left(\mathrm{mg} \mathrm{kg}^{-1}\right)\end{array}$} & \multicolumn{4}{|c|}{ Recovery (\%) } & \multirow{2}{*}{$\begin{array}{c}\text { LOQ } \\
\left(\mathrm{mg} \mathrm{kg}^{-1}\right)\end{array}$} \\
\hline & & Re.1 & Re. 2 & Re. 3 & Mean $^{\mathrm{a})} \pm \mathrm{C} . \mathrm{V}^{\mathrm{b})}$ & \\
\hline \multirow{2}{*}{ Soil 1} & 0.2 & 86.6 & 88.9 & 83.8 & $86.5 \pm 3.0$ & \multirow{2}{*}{0.02} \\
\hline & 1.0 & 92.9 & 89.1 & 88.1 & $90.0 \pm 2.8$ & \\
\hline \multirow{2}{*}{ Soil 2} & 0.2 & 82.1 & 93.2 & 84.4 & $86.6 \pm 6.8$ & \multirow{2}{*}{0.02} \\
\hline & 1.0 & 89.1 & 93.5 & 86.8 & $89.8 \pm 3.8$ & \\
\hline \multirow{2}{*}{ Korean Cabbage } & 0.2 & 90.0 & 93.4 & 92.8 & $92.1 \pm 2.0$ & \multirow{2}{*}{0.02} \\
\hline & 1.0 & 84.7 & 83.0 & 82.7 & $83.5 \pm 1.3$ & \\
\hline
\end{tabular}

a) Average of triplicate

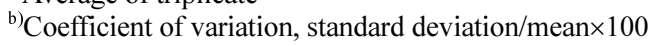



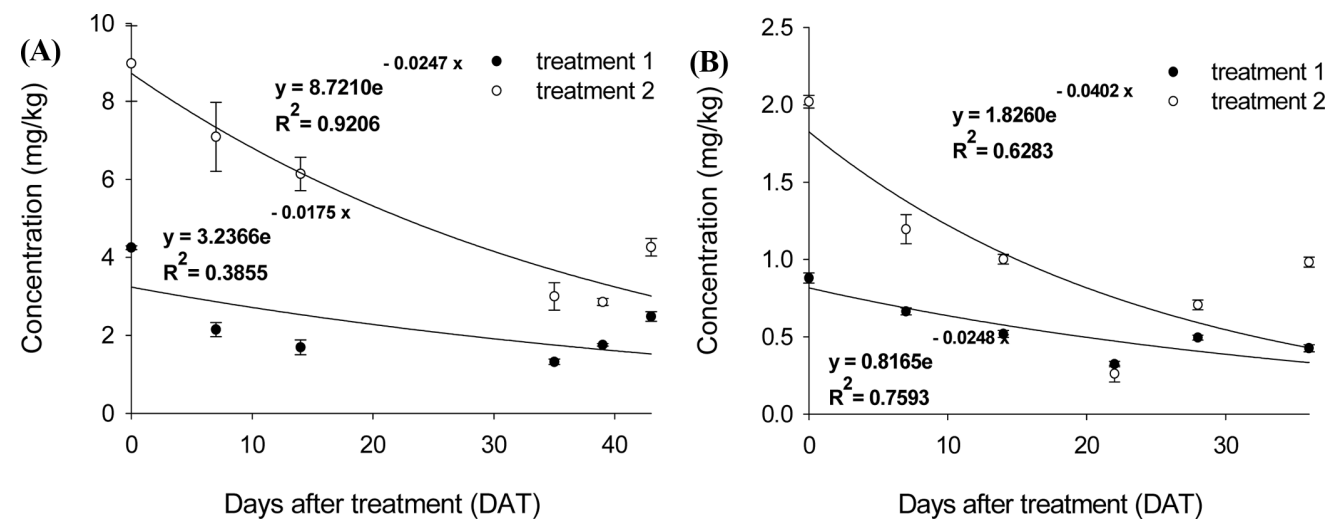

Fig. 2 Degradation curve of tricyclazole in soil 1 (A) and 2 (B). (treatment 1; low concentration treated, treatment 2; high concentration treated)
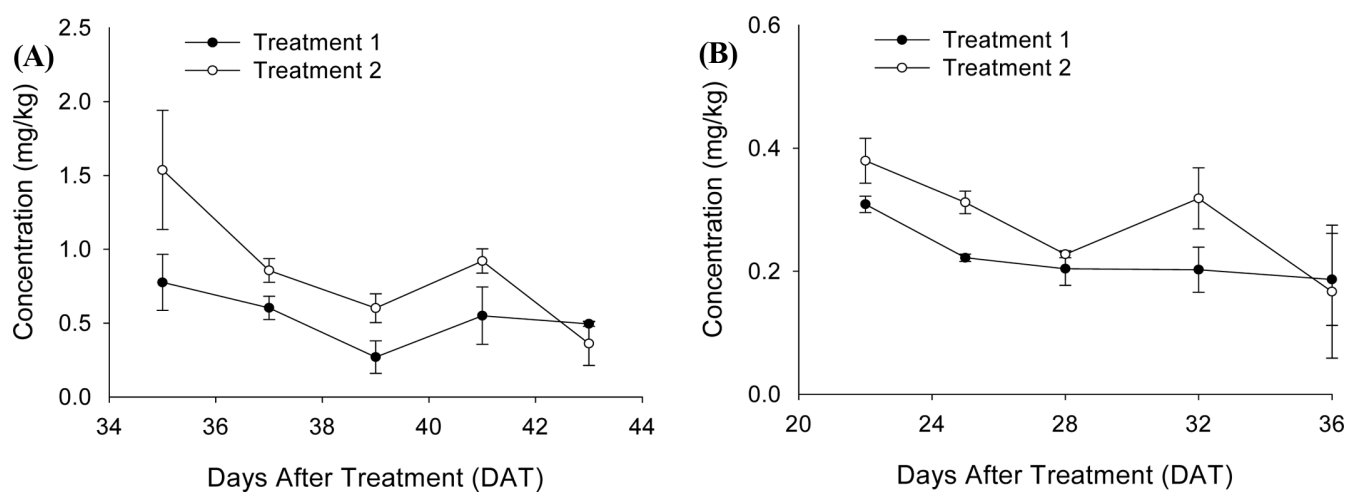

Fig. 3 Concentration of tricyclazole grown in tricyclazole treated soil 1 (A) and 2 (B). (treatment 1; low concentration treated, treatment 2; high concentration treated)

잔류량은 $2.02 \mathrm{mg} \mathrm{kg}^{-1}$ 이었으며 36 일 후에는 $0.98 \mathrm{mg} \mathrm{kg}^{-1}$ 로 감소하였다.

잔류 감소 회귀식은 저농도 처리구는 $\mathrm{C}_{\mathrm{t}}=0.8165 \mathrm{e}^{-0.0248 \mathrm{t}}\left(\mathrm{R}^{2}\right.$ $=0.7593)$, 고농도 처리구는 $\mathrm{C}_{\mathrm{t}}=1.8260 \mathrm{e}^{-0.0402 \mathrm{t}}\left(\mathrm{R}^{2}=0.6283\right)$ 이었 고, 이 식에 따라서 산출된 포장 2 재배토양 중 반감기는 각각 27.9, 17.2일 이었다.

토양 중 농약의 반감기는 토양의 종류, 유기물 함량등에 크 게 영향을 받는것으로 알려져 있다. 포장 2 토양의 유기물함량 이 높고, 식질의 분포가 높은 양토로서 유기화합물의 흡착량이 높아 반감기가 길어진 것으로 판단된다(Jeon 등, 2014).

\section{엇갈이 배추 중 잔류량 변화}

포장 1 재배 엇갈이배추 중 tricyclazole의 잔류량은 저농도 처 리 후 35 일차 수확 시 $0.78 \pm 0.19 \mathrm{mg} \mathrm{kg}^{-1}$ 이었으며 경과일에 따 라 감소하여 43 일 후 수확 시 $0.50 \pm 0.02 \mathrm{mg} \mathrm{kg}$-이었다. 고농도 처리 후 35 일차 수확 시료 중 잔류량은 $1.54 \pm 1.40 \mathrm{mg} \mathrm{kg}^{-1}$ 이었 으며 43일 후 수확 시 $0.36 \pm 0.15 \mathrm{mg} \mathrm{kg}^{-1}$ 로 감소하였다.

포장 2 엇갈이 배추 중 잔류량은 저농도 처리 후 22 일차 수 확 시 $0.31 \pm 0.01 \mathrm{mg} \mathrm{kg}^{-1}$ 이었으며 35 일 후 수확 시 $0.19 \pm 0.07$ $\mathrm{mg} \mathrm{kg}^{-1}$ 로 감소되었다. 고농도 처리 후 22일차 수확 시료 중 잔 류량은 $0.38 \pm 0.04 \mathrm{mg} \mathrm{kg}^{-1}$ 이었으며 35 일 후 수확 시 $0.17 \pm 0.11$ $\mathrm{mg} \mathrm{kg}^{-1}$ 로 감소하였다(Fig. 3).

시험포장 1 에서 초기 토양 잔류량 대비 작물잔류량은 평균
$11.11 \%$ 이고, 최고치는 처리구 1 의 35 일차 $18.26 \%$, 최저치는 처 리구 2 의 43 일차에 $4.03 \%$ 이었다.

시험포장 2 에서는 초기 토양 잔류량 대비 작물잔류량은 평균 $19.72 \%$ 이고, 최고치는 처리구 1 의 22 일차 $35.08 \%$, 최저치는 35 일차에 처리구 1 의 $8.26 \%$ 이었다(Fig. 4 ).

재배 기간 중 토양에서 엇갈이배추로 전이되는 tricyclazole의 농도는 재배 기간이 경과할수록 감소하였다. 태양의 광분해 및 작물의 생장에 의해 생체량 증가 따라서 감소율이 증가하였다 는 것으로 판단된다(Park 등, 2009).

Boscalid 및 chlorfenapyr 처리된 토양에서 재배된 엇갈이배추 중 잔류량을 분석한 결과 boscalid의 경우 저농도구와 고농도구 에서 각각 2.77 및 $5.66 \mathrm{mg} / \mathrm{kg}$ 이었고 chlorfenapyr의 경우 각 처리구에서 2.38 및 $6.43 \mathrm{mg} / \mathrm{kg}$ 으로 나타났다. 시간이 지나면서 토양 중 잔류량은 감소하였고 엇갈이 배추의 경우 28 일 후 boscalid 흡수량은 저농도 처리구에서 $2.47 \mathrm{mg} / \mathrm{kg}$ 으로 흡수율은 $2.4 \%$ 이였으며, 고농도 처리구에서 $4.71 \mathrm{mg} / \mathrm{kg}$ 으로 흡수율은 $2.2 \%$ 이었고, chlorfenapyr의 흡수량은 저농도와 고농도 처리구 에서 각각 1.36 및 $2.63 \mathrm{mg} / \mathrm{kg}$ 으로 나타나 1.5 및 $1.3 \%$ 흡수 율을 보였다(Jeon 등, 2014). 이렇듯 같은 작물일지라도 살포한 약제에 따라 흡수율이 나타날수 있고, 여러 요인 중 하나인 작 물에 대한 흡수성은 $\log \mathrm{P}$ 값이 낮고 물에 대한 용해도가 높을 수록 강하게 나타난다고 알려져 있다(Juraske 등, 2011; Hwang 등, 2014; Lu 등, 2014; Jeon 등, 2014). 


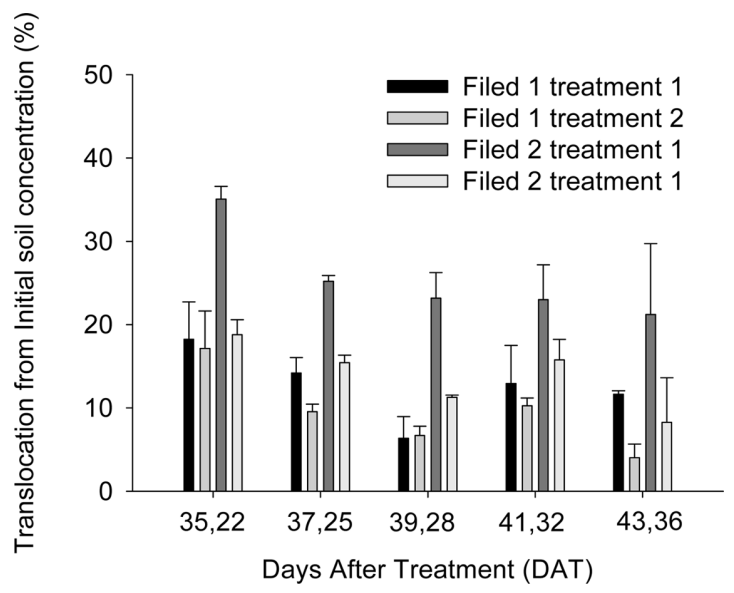

Fig. 4 Translocation of tricyclazole compared to soil initial concentration. (treatment 1; low concentration treated, treatment 2; high concentration treated)

Tricyclazole, boscalid, chlorfenapyr의 $\log \mathrm{P}$ 값은 각각 $1.42,2.96$ 및 4.83 이며 물에 대한 용해도는 각각 $596,4.6$ 및 $3.56 \mathrm{mg} / \mathrm{L}$ 으로 (Jeon 등, 2014; Tomlin 2015) 이들 세 약제 중, $\log \mathrm{P}$ 값이 낮고 물에 대한 용해도가 높은 tricyclazole의 작물 전이량이 다른 약제들 보다 높은 것으로 판단된다.

\section{토양 Tricyclazole의 관리농도 제안}

엇갈이배추 중 tricyclazole의 MRL이 설정되어 있지 않지만 PLS제도에서 요구하는 불검출 기준은 $0.01 \mathrm{mg} / \mathrm{kg}$ 이다. 이 이하 로 잔류하기 위해서는 배추의 최대 전이량인 $35.08 \%$ 가정했을 때 초기 재배 토양 잔류량이 $0.03 \mathrm{mg} / \mathrm{kg}$ 이하라면 배추를 수확 시 잔류량이 $0.01 \mathrm{mg} / \mathrm{kg}$ 이하 일것으로 계산되어 엇갈이 배추 재배 토양 중 tricyclazole 관리농도는 $0.03 \mathrm{mg} / \mathrm{kg}$ 으로 제안할 수 있다.

\section{초 록}

본 연구에서는 tricyclazole을 대상으로 작물재배 토양 중에 잔 류된 tricyclazole의 잔류 소실 및 엇갈이 배추로의 전이량을 구 명하고자 하였다. Tricyclazole은 농작물 재배 시 사용하지 않았 으나 경작지 토양에서 다수 검출되는 성분 중 하나이다. 포장 시험은 광주(시험포장 1)와 용인(시험포장 2)의 시설재배지 두 곳에서 실시하였다. Tricyclazole을 토양 중 서로 다른 두 농도 로 처리한 후, 토양과 엇갈이 배추를 채취하였다. 토양과 엇갈 이 배추 중 평균 회수율 범위는 83.5-92.1\%이었고, 변이계수는 1.3-6.8\%였다. Tricyclazole의 초기 토양 농도는 시험포장 1 에서 $4.25,8.97 \mathrm{mg} \mathrm{kg}^{-1}$ 이었으며 농약 처리 43 일 후에 $2.48,4.26$ $\mathrm{mg} \mathrm{kg}^{-1}$ 로 감소하였고, 시험포장 2에서는 초기 토양 농도가 $0.88,2.02 \mathrm{mg} \mathrm{kg}^{-1}$ 이었고 농약 처리 36 일 후에 $0.43,0.98 \mathrm{mg}$ $\mathrm{kg}^{-1}$ 으로 감소하였다. 시험포장 1 에서의 토양 중 반감기는 저농 도와 고농도 처리구에서 $39.6,28.1$ 일 이었으며, 시험포장 2에 서는 $27.9,17.2$ 일 이었다. 엇갈이배추로 전이된 tricyclazole 잔 류량은 시험포장 1과 2에서 초기 토양잔류농도 대비 각각 4.03$18.26 \%, 8.26-38.05 \%$ 범위였다.

\section{Keywords 살균제 - 얼갈이 배추 - 전이량 - 트리사이클라졸}

감사의 글 본 연구는 농촌진흥청 공동연구사업 “재배환경 중 잔류농약의 작물흡수이행 연구(PJ010876012017)"의 지원에 의하여 이루어 진 것으로 이 에 감사드립니다.

\section{References}

Hwang IY, Choi EJ, Roh JK (1985) Evaluation for safety of tricyclazole (I). Kor J Environ Agric 3: 1-5

Hwang JI, Jeon SO, Lee SH, Hur JH, Kim KR, Kim JE (2014) Distribution patterns of organophosphorous insecticide chlorpyrifos absorbed from soil into cucumber. Kor J Pesti Sci 18: 148-155

Jeon SO, Hwang JI, Lee SH, Kim JE (2014) Uptake of boscalid and chlorfenapyr residues in soil into Korean cabbage. Kor J Pesti Sci. 18: 314-320

Juraske R, Vivas CSM, Velasquez AE, Santos GG, Moreno MBB, Gomez JD, Binder CR, Hellweg S, Dallos JAG (2011) Pesticide uptake in potatoes: model and field experiments. Environ Sci Technol 45: 651-657

KCPA (2016) Using guideline of crop protection agents. Korea Crop Protection Association, Samjung Inc., Seoul

KFDA (2015) Practical manual for pesticide residue analysis in food code. 11-1470550-000004-14, Korea Food \& Drug Administration, Osong

Kim JH, Choe JH, Lee HG (2017) Safe use of pesticides for pesticide stability and comprehensive management of pests. National Institute of Agricultural Sciences. http://www2.rda.go.kr/kpms/ipsm/Korean/03_undp/morgue/bc/ bc2 6.htm Accessed 17 July 2017

Lu MX, Jiang WW, Wang JL, Jian Q, ShenY, Liu XJ, Yu XY (2014) Persistence and dissipation of chlorpyrifos in brassica chinensis, lettuce, celery, asparagus lettuce, eggplant, and pepper in a greenhouse. Plos One 9(6): $1-8$

Ministry of Food and Drug Safety (2017) http://www.foodsafetykorea.go.kr/ foodcode/02_01.jsp. Accessed 17 July 2017

National Agricultural Quality Service (2017) Results of the 2016 Agricultural Product Safety Survey released. http://www.naqs.go.kr/ Accessed 17 July 2017

Park BJ, Lee BM, Kim CS, Park KH, Kim JH, Kwon HY, Park SW, Choi GH, Lim SJ (2013) Long-term monitoring of pesticide residues in arable soils in Korea. Kor J Pesti Sci 17: 283-292

Park SY, Jung JK, Kang JM, Kim SH, Yang JY, Kang SA, Chun HK, Park KY (2009) Monitoring of 160 kinds of pesticide residues in commercial baechu (Chinese) cabbage throughout the year. J Korean Soc Food Sci Nutr 38(7): 970-975

Phong TK, Nhung DTT, Motobayashi T, Thuyet DQ, Watanabe H (2009) Fate and transport of nursery-box-applied tricyclazole and imidacloprid in paddy Fields. Water Air Soil Pollut 202: 3-12

Tomlin CDS (2015) Metamifop. In: A world compendium The Pesticide Manual $15^{\text {th }} \mathrm{ED}$; Tomlin CDS Eds; British Crop Protection Council, Alton, Hampshire, pp 1163-1164 